\title{
Early and Late Stimulation of ob mRNA Expression in Meal-Fed and Overfed Rats
}

\author{
Ruth B.S. Harris, Timothy G. Ramsay, Steven R. Smith, and Richard C. Bruch* \\ Pennington Biomedical Research Center and *Department of Zoology and Physiology, Louisiana State University, Baton Rouge, \\ Louisiana 70808
}

\begin{abstract}
ob protein is hypothesized to be a circulating feedback signal in the regulation of energy balance. Obese, overfed rats have high levels of ob mRNA expression and suppressed voluntary food intake, indicating the presence of a potent satiety factor. The objectives of this experiment were to determine whether feeding rats their normal daily intake in three meals, compared with ad libitum feeding, increased ob mRNA expression and to determine the degree of obesity required to stimulate expression of ob mRNA. Rats were fed ad libitum, were tube-fed their normal intake in three meals a day, or were tube-fed twice normal intake. ob mRNA was measured by Northern blot analysis after $0,2,7,14,21$, and $32 \mathrm{~d}$ of tube-feeding. After only $2 \mathrm{~d}$ ob mRNA was threefold higher in tube-fed animals than in ad libitum controls. By day 21 there was a further increase in ob mRNA expression in overfed rats which were at $130 \%$ control weight. These results suggest that a metabolic consequence of meal-feeding increases ob mRNA expression in the absence of increased food intake or weight gain. There is a further increase in ob mRNA expression once significant obesity is established. (J. Clin. Invest. 1996. 97:2020-2026.) Key words: obesity • rats $\bullet$ energy balance $\bullet$ ob protein $\cdot$ Northern blot
\end{abstract}

\section{Introduction}

Parabiosis experiments with obese mice $(1,2)$ or rats $(3,4)$ demonstrated the involvement of circulating factors as feedback signals in the regulation of energy balance. Zhang et al. (5) recently used positional cloning to identify one such potential signal that is mutated in genetically obese $o b / o b$ mice. The signal protein, ob protein or leptin, is a peptide produced exclusively in adipose tissue. It is hypothesized to work in the brain to inhibit feeding and correct food intake during conditions of positive energy balance and weight gain. It may also have some, as yet undefined, direct effects on peripheral energy metabolism.

ob mRNA expression has been shown to be increased in genetically obese mice (5), rats made obese by ventromedial hypothalamic lesions (6), and obese humans (7). Peripheral administration of low doses of the protein to obese $o b / o b$ mice

Address correspondence to Ruth Harris, Pennington Biomedical Research Center, 6400 Perkins Road, Baton Rouge, LA 70808. Phone: 504-763-2521; FAX: 504-763-2525; E-mail: harrisrb@mhs.pbrc.edu

Received for publication 10 November 1995 and accepted in revised form 7 February 1996.

J. Clin. Invest.

(C) The American Society for Clinical Investigation, Inc.

0021-9738/96/05/2020/07 \$2.00

Volume 97, Number 9, May 1996, 2020-2026 corrects their hypothermia, hyperinsulinemia and hyperglycemia. Higher doses suppress food intake and cause weight loss (8). ob protein will also inhibit feeding in $o b / o b$ mice when administered centrally, confirming the presence of receptors in the brain for the hypothesized feedback signal (9). Substantially increased doses of protein are required to produce a significant effect on food intake or body weight of normal mice (10). The protein has no effect in genetically obese $d b / d b$ mice which are thought to have a defective receptor signaling system for ob protein $(9,10)$.

The objective of this experiment was to determine the degree of obesity required to induce an increase in the level of expression of ob protein mRNA in adipose tissue of rats made obese by dietary means. Weight gain was induced by tubefeeding rats twice their normal food intake whereas tube-fed controls received their normal intake. The food was delivered in three meals a day by stomach tube. Delivery of food in three gavaged meals allowed a comparison of ob protein mRNA expression in meal-fed animals with that in ad libitum fed animals in addition to comparisons between animals that were made obese and their tube-fed controls. Overfeeding by tube-feeding causes a steady and uniform weight gain in the animals. In a previous experiment using this model, when tube-feeding was stopped the voluntary intake of the rats was drastically reduced until body weight had returned close to control levels (11), suggesting the presence of a potent inhibitor of food intake related to body fat content. Preliminary data (not shown) demonstrated that retroperitoneal adipose ob mRNA expression in rats fed twice their normal intake for $30 \mathrm{~d}$ was increased to levels similar to those in genetically obese $d b / d b$ mice. Therefore, this was an ideal model for examining the degree of change in body fat content required to stimulate ob expression. In addition to examining the time course of changes in expression, ob mRNA was measured in four different fat pads to determine site specificity of response.

\section{Methods}

Female Sprague Dawley rats (Harlan Sprague Dawley, Indianapolis, IN), weighing approximately 200 grams, were housed singly and during a 10-d control period had free access to the diet described in Table I. Daily food intakes and body weights were recorded. The rats were divided into 12 groups matched for average body weight. One group of six rats was killed for baseline measurements (day 0). Five rats continued to eat ad libitum. All other rats were tube-fed three meals a day using the same diet as had been offered ad libitum. Five groups of five or six rats were tube-fed $100 \%$ of the average daily intake recorded during the control period (17.6 grams/rat in three 8.2$\mathrm{ml}$ meals/d). Five groups of eight rats were initially fed $100 \%$ intake and meal size was gradually increased so that by day 7 food intake was doubled. It was held at $200 \%$ until the end of the experiment. The number of animals that were overfed was greater than that of controls, since the serum from these animals was required for another study requiring eight replicates per group. All procedures were approved by the Animal Care and Use Committee of the Pennington Biomedical Research Center. 
Table I. Diet Composition

\begin{tabular}{lr}
\hline \multicolumn{1}{c}{ Ingredient } & grams $/ \mathrm{kg}$ \\
\hline Casein & 200 \\
Dextrose & 604 \\
Corn oil & 100 \\
AIN mineral mix & 40 \\
AIN 76 vitamin mix & 22 \\
Methionine & 4 \\
\end{tabular}

The diet was fed ad libitum as a dry diet during the 10-d control period and to the ad libitum group throughout the experiment. It was mixed with water to a final concentration of $1 \mathrm{gram} / 1.4 \mathrm{ml}$ for tube-feeding.

On days $2,7,14$, and 21 , one of each group of $100 \%$-fed and $200 \%$-fed rats was killed. On day 32 the final groups of ad libitum, $100 \%$-fed, and $200 \%$-fed rats were killed. Rats received their usual morning meal at 6:30 a.m. Between 9:00 a.m. and 12:00 p.m. they were decapitated and blood was collected. Inguinal, retroperitoneal, perirenal, and gonadal fat pads were dissected, weighed, snap frozen in liquid nitrogen, and stored at $-80^{\circ} \mathrm{C}$. The adrenal glands were also dissected and weighed. Small samples of retroperitoneal, perirenal, and inguinal fat were weighed and fixed in osmium tetroxide for determination of cell number and size distribution by Coulter Counter and Channelizer analysis (Coulter Corp., Hialeah, FL), as described previously (12). These samples were collected from the ad libitum rats killed on day 0 and from five rats in each of the $200 \%$-fed groups at subsequent time points. As cellularity was measured in only five of the eight rats in each overfed group, a representative sampling was obtained by excluding the heaviest, lightest, and median weight rat in each group.

Serum was collected and frozen at $-80^{\circ} \mathrm{C}$ for subsequent determination of glucose by enzymatic colorimetric assay (kit No. 510; Sigma Chemical Co., St. Louis, MO), insulin by radioimmunoassay (Linco Research Inc., St. Charles, MO), and corticosterone by radioimmunoassay (ICN Biomedicals, Inc., Irvine, CA). Total RNA was extracted from samples of adipose tissue using TriZol reagent (GIBCO-BRL, Gaithersburg, MD). RNA was diluted in formamide, concentration was measured spectrophotometrically, and integrity was determined by agarose gel electrophoresis. ob mRNA was measured in retroperitoneal fat from five rats in each group and in all four fat pads from five animals from the groups from days $0,2,14$, and 32 .

ob mRNA was detected by Northern blot analysis using a cDNA probe. PCR primers were designed using Primer (Whitehead Institute for Biomedical Research, Boston, MA) and synthesized by GeneLab (Louisiana State University). The sequence of the $3^{\prime}$ primer was TCATTGGCTATCTGCAGCAC and of the $5^{\prime}$ primer was AAGAAGATCCCAGGGAGGAA. Total RNA was isolated from the retroperitoneal fat of a female Sprague Dawley rat that had been $200 \%$-fed for 30 d. cDNA was synthesized using a Superscript Preamplification System kit (GIBCO-BRL). ob cDNA was amplified by PCR performed for 30 cycles with 1 min of denaturation at $94^{\circ} \mathrm{C}, 1$ min of annealing at $55^{\circ} \mathrm{C}$, and $3 \mathrm{~min}$ of extension at $72^{\circ} \mathrm{C}$ using $1 \mu \mathrm{g}$ cDNA, $1 \mu \mathrm{M} 3^{\prime}$ primer, $1 \mu \mathrm{M} 5^{\prime}$ primer, and $5 \mathrm{U}$ Taq DNA polymerase. The resulting 320-bp PCR product was ligated into pCRTMII vector with T4 DNA ligase (TA cloning kit; Invitrogen, San Diego, CA) and transformed into competent Escherichia coli (DH5a cells; GIBCO-BRL). Positive colonies were selected by blue/white screening. Bases 12-332 of the resulting 342-bp cDNA probe had 96\% homology with bases 36-356 of mouse ob mRNA and bases 33332 of the probe had $86 \%$ homology with bases 1-299 of human ob mRNA. In Northern blot analysis the probe detected a single mRNA species for rat and for mouse adipose tissue. The size of ob mRNA was determined to be $3.9 \mathrm{~kb}$ using an RNA ladder (GIBCO-BRL).
The size of $28 \mathrm{~S}$ rRNA was determined to be $5.0 \mathrm{~kb}$ on the same gels. ob mRNA was not detected in liver or brain from either overfed rats or $o b / o b$ obese mice (data not shown).

For Northern blot analysis 5- $\mu$ g samples of total RNA were separated in a $1.2 \%$ agarose, $2.2 \mathrm{M}$ formaldehyde gel in $1 \times$ Mops buffer. RNA was transferred to a nylon membrane (Hybond; Amersham Corp., Arlington Heights, IL) by capillary transfer with $20 \times$ SSC and immobilized by exposure to ultraviolet light. Membranes were prehybridized with RapidHyb buffer (Amersham Corp.) at $65^{\circ} \mathrm{C}$ for $1 \mathrm{~h}$. Buffer was replaced with fresh RapidHyb containing heat-denatured radiolabeled probe ( $5 \mathrm{ng}$ probe, $\sim 1.4 \mu \mathrm{Ci} / \mathrm{ng} \mathrm{DNA}$ ) and hybridization continued at $65^{\circ} \mathrm{C}$ for $3 \mathrm{~h}$. Radiolabeled probe was synthesized using a Multiprime DNA labeling kit (Amersham Corp.) and $\left[{ }^{32} \mathrm{P}\right] \mathrm{dCTP}$ (DuPont/New England Nuclear, Wilmington, DE). Membranes were rinsed twice with $2 \times$ SSC and $0.1 \%$ SDS at room temperature for $15 \mathrm{~min}$ and once with $1 \times \mathrm{SSC}, 0.1 \% \mathrm{SDS}$ at $65^{\circ} \mathrm{C}$ before being exposed to a phosphorimaging screen overnight. ob mRNA was quantified using a Molecular Devices PhosphorImager (Molecular Dynamics, Sunnyvale, CA) and Imagequant computer software (Molecular Dynamics).

Each membrane was stripped by exposure to boiling $0.1 \%$ SDS and rehybridized with a 29-base human $28 \mathrm{~S}$ oligonucleotide probe (CLONTECH, Palo Alto, CA). The oligonucleotide was 5'-end labeled (5' DNA terminus labeling system; GIBCO-BRL) with $\left[\gamma^{-}{ }^{32} \mathrm{P}\right]$ ATP (DuPont/New England Nuclear). Membranes were prehybridized for $30 \mathrm{~min}$ in RapidHyb buffer at $42^{\circ} \mathrm{C}$. Buffer was replaced with fresh RapidHyb containing the radiolabeled oligonucleotide and hybridized for $2 \mathrm{~h}$ at $42^{\circ} \mathrm{C}$. The membranes were washed twice at room temperature for $20 \mathrm{~min}$ in $5 \times \mathrm{SSC}, 0.1 \%$ SDS and exposed to a phosphorimaging screen overnight, and $28 \mathrm{~S}$ ribosomal RNA was quantified by phosphorimaging.

The relative level of expression of ob mRNA was determined as the ratio of the density of the ob band to the density of the 28S rRNA band. To account for variability between blots each membrane included a sample from a pool of gonadal fat RNA. ob mRNA/28S rRNA in this internal standard was arbitrarily set at 2.0 and ratios from all blots were expressed relative to this value. When retroperitoneal mRNA was analyzed, each blot contained pairs of $100 \%$-fed and $200 \%$-fed samples from each day on which rats were killed. Comparisons between different fat depots were measured using blots containing samples from each fat depot, including retroperitoneal, of a $100 \%$-fed rat and a $200 \%$-fed rat from the same day of the experiment.

Results from Northern blot analysis were analyzed by two-way ANOVA and when significant effects of time or feeding level were indicated the results were compared by one-way ANOVA and calculation of least significant difference at $P<0.05$ or two-tailed Student's $t$ test, as appropriate. To investigate which physiological changes induced by tube-feeding were associated with ob mRNA steady state concentration, correlations between level of ob mRNA and serum insulin, corticosterone, fat pad weight, fat pad cell number, and the median size of the large adipocytes were determined, assuming a linear relationship. All statistical analyses were performed using Microsoft Excel 5.0 (Microsoft Corp., Seattle, WA).

\section{Results and Discussion}

At the start of tube-feeding all groups were weight matched at 245-247 grams. Once overfeeding was established, the $200 \%$ fed rats gained weight steadily and by day 32 were $160 \%$ of control weight. On day 32 the weights of ad libitum and $100 \%$ fed rats were significantly different although there were no statistically significant differences in fat pad weights (see Table II). As shown in Table II, overfeeding with a high carbohydrate diet caused a significant increase in body fat content. There was no effect on adrenal weight, implying that tube- 
Table II. Body Composition

\begin{tabular}{|c|c|c|c|}
\hline & Ad Libitum & $100 \%$-Fed & $200 \%-F e d$ \\
\hline \multicolumn{4}{|c|}{ Live weight (grams) } \\
\hline Day 0 & $247 \pm 6$ & & \\
\hline Day 2 & & $247 \pm 7$ & $247 \pm 5$ \\
\hline Day 7 & & $255 \pm 7$ & $278 \pm 5^{*}$ \\
\hline Day 14 & & $259 \pm 6$ & $323 \pm 6^{\ddagger}$ \\
\hline Day 21 & & $263 \pm 6$ & $353 \pm 7^{\ddagger}$ \\
\hline Day 32 & $259 \pm 7^{\mathrm{A}}$ & $273 \pm 4^{\mathrm{B}}$ & $408 \pm 4^{C}$ \\
\hline \multicolumn{4}{|c|}{ Retroperitoneal fat (grams) } \\
\hline Day 0 & $1.3 \pm 0.2$ & & \\
\hline Day 2 & & $1.4 \pm 0.2$ & $1.2 \pm 0.1$ \\
\hline Day 7 & & $1.7 \pm 0.2$ & $2.1 \pm 0.1$ \\
\hline Day 14 & & $1.5 \pm 0.1$ & $3.4 \pm 0.4^{\ddagger}$ \\
\hline Day 21 & & $1.9 \pm 0.1$ & $5.3 \pm 0.3^{\ddagger}$ \\
\hline Day 32 & $1.6 \pm 0.3^{\mathrm{A}}$ & $1.8 \pm 0.1^{\mathrm{A}}$ & $6.7 \pm 0.3^{\mathrm{B}}$ \\
\hline \multicolumn{4}{|c|}{ Inguinal fat (grams) } \\
\hline Day 0 & $2.8 \pm 0.3$ & & \\
\hline Day 2 & & $3.2 \pm 0.3$ & $2.9 \pm 0.1$ \\
\hline Day 7 & & $3.7 \pm 0.3$ & $4.7 \pm 0.3 *$ \\
\hline Day 14 & & $4.0 \pm 0.4$ & $8.1 \pm 0.5^{\ddagger}$ \\
\hline Day 21 & & $4.2 \pm 0.2$ & $11.1 \pm 0.4^{\ddagger}$ \\
\hline Day 32 & $3.6 \pm 0.5^{\mathrm{A}}$ & $4.0 \pm 0.2^{\mathrm{A}}$ & $15.7 \pm 0.7^{\mathrm{B}}$ \\
\hline \multicolumn{4}{|c|}{ Perirenal fat } \\
\hline Day 0 & $1.3 \pm 0.2$ & & \\
\hline Day 2 & & $0.7 \pm 0.1$ & $1.0 \pm 0.1$ \\
\hline Day 7 & & $1.1 \pm 0.1$ & $1.6 \pm 0.2$ \\
\hline Day 14 & & $1.2 \pm 0.2$ & $2.2 \pm 0.1^{\ddagger}$ \\
\hline Day 21 & & $1.4 \pm 0.2$ & $3.7 \pm 0.2^{\ddagger}$ \\
\hline Day 32 & $1.2 \pm 0.2^{\mathrm{A}}$ & $1.2 \pm 0.1^{\mathrm{A}}$ & $6.0 \pm 0.4^{\mathrm{B}}$ \\
\hline \multicolumn{4}{|c|}{ Gonadal fat } \\
\hline Day 0 & $3.5 \pm 0.3$ & & \\
\hline Day 2 & & $4.0 \pm 0.6$ & $4.4 \pm 0.3$ \\
\hline Day 7 & & $5.1 \pm 0.3$ & $6.9 \pm 0.6^{*}$ \\
\hline Day 14 & & $5.6 \pm 0.5$ & $9.8 \pm 0.9 *$ \\
\hline Day 21 & & $5.9 \pm 0.4$ & $13.1 \pm 0.6^{\ddagger}$ \\
\hline Day 32 & $4.9 \pm 0.5^{\mathrm{A}}$ & $6.3 \pm 0.4^{\mathrm{A}}$ & $19.1 \pm 1.0^{\mathrm{B}}$ \\
\hline \multicolumn{4}{|c|}{ Adrenal weight (mg) } \\
\hline Day 0 & $85 \pm 6$ & & \\
\hline Day 2 & & $84 \pm 3$ & $85 \pm 3$ \\
\hline Day 7 & & $74 \pm 2$ & $72 \pm 4$ \\
\hline Day 14 & & $71 \pm 1$ & $81 \pm 3$ \\
\hline Day 21 & & $76 \pm 5$ & $83 \pm 2$ \\
\hline Day 32 & $94 \pm 9$ & $86 \pm 8$ & $106 \pm 7$ \\
\hline
\end{tabular}

Data are means \pm SEM. Significant differences $\left({ }^{*} P<0.05,{ }^{\ddagger} P<0.001\right)$ were determined by unpaired Student's $t$ test on days 2-21. On day 32, differences, indicated by superscript, were determined by one-way ANOVA and calculation of least significant difference at $P<0.05$.

feeding is not a severe chronic stress. This was confirmed by measurements of serum corticosterone concentration.

The results from serum analyses are shown in Table III. There were large ranges in serum insulin, glucose, and corticosterone for each group of animals as they were killed soon after their last meal. There were no significant differences in serum glucose except between ad libitum and tube-fed rats on day 32. This difference was probably reflective of differences
Table III. Serum Insulin, Glucose, and Corticosterone

\begin{tabular}{|c|c|c|c|}
\hline & Ad Libitum & $100 \%-\mathrm{Fed}$ & $200 \%$-Fed \\
\hline \multicolumn{4}{|c|}{ Glucose $(\mathrm{mg} / \mathrm{dl})$} \\
\hline Day 0 & $139 \pm 4$ & & \\
\hline Day 2 & & $158 \pm 10$ & $168 \pm 11$ \\
\hline Day 7 & & $145 \pm 12$ & $161 \pm 8$ \\
\hline Day 14 & & $144 \pm 3$ & $153 \pm 8$ \\
\hline Day 21 & & $157 \pm 8$ & $165 \pm 12$ \\
\hline Day 32 & $134 \pm 3^{\mathrm{A}}$ & $157 \pm 6^{\mathrm{B}}$ & $159 \pm 7^{\mathrm{B}}$ \\
\hline \multicolumn{4}{|c|}{ Insulin (ng/ml) } \\
\hline Day 0 & $0.6 \pm 0.1$ & & \\
\hline Day 2 & & $2.3 \pm 0.5$ & $6.6 \pm 2.7$ \\
\hline Day 7 & & $1.2 \pm 0.3$ & $12.2 \pm 2.7^{*}$ \\
\hline Day 14 & & $2.1 \pm 0.8$ & $6.0 \pm 1.3 *$ \\
\hline Day 21 & & $1.8 \pm 0.5$ & $8.1 \pm 1.8^{*}$ \\
\hline Day 32 & $0.7 \pm 0.1^{\mathrm{A}}$ & $2.9 \pm 1.3^{\mathrm{A}}$ & $7.5 \pm 1.6^{\mathrm{B}}$ \\
\hline \multicolumn{4}{|c|}{ Corticosterone (ng/ml) } \\
\hline Day 0 & $29 \pm 5$ & & \\
\hline Day 2 & & $54 \pm 15$ & $147 \pm 76$ \\
\hline Day 7 & & $100 \pm 57$ & $81 \pm 41$ \\
\hline Day 14 & & $53 \pm 24$ & $50 \pm 13$ \\
\hline Day 21 & & $71 \pm 41$ & $55 \pm 16$ \\
\hline Day 32 & $40 \pm 8$ & $85 \pm 26$ & $30 \pm 3$ \\
\hline
\end{tabular}

Data are means \pm SEM for groups of five to eight rats. An asterisk indicates a significant difference $(P<0.05)$ determined by unpaired Student's $t$ test. Values for glucose or insulin on day 32 with different superscripts are significantly different $(P<0.05)$ determined by one-way ANOVA.

in feeding regimen. The normoglycemia of postprandial $200 \%-$ fed rats indicates that, even though they had gained substantial amounts of body fat by day 32 , peripheral tissue was insulin responsive and able to clear large boluses of glucose from the circulation, preventing the development of hyperglycemia. However, as serum insulin was significantly increased in overfed rats from day 7 of the experiment, it appeared that the rats had become insulin insensitive at an early stage of weight gain, requiring higher concentrations of insulin than normal to maintain normoglycemia.

Fat cell numbers for perirenal, inguinal, and retroperitoneal fat in ad libitum rats killed on day 0 and for five rats from each group of $200 \%$-fed rats from subsequent time points are given in Table IV. Cell size distributions for the different pads are illustrated in Figs. 1-3. Cell number increased in all of the fat pads as overfeeding progressed. There was a significant increase in inguinal cell number as early as day 2 , before overfeeding had been established. As increased adiposity is initially achieved by filling of existing adipocytes (13), the early changes in cell number probably represented filling of existing small adipocytes which were too small to be monitored by the Channelizer. In this experiment it was not possible to measure adipocytes smaller than $30 \mu \mathrm{m}$ in diameter. Therefore, it was impossible to determine when true hyperplasia occurred; however, the second dramatic change in the number of small cells between days 14 and 21 may be representative of true proliferation. By the end of the experiment cell numbers in all pads of the $200 \%$-fed rats were increased at least fivefold compared 


\begin{tabular}{lccc}
\hline & Perirenal & Retroperitoneal & Inguinal \\
\hline $\begin{array}{c}\text { Ad Libitum } \\
\text { Day 0 }\end{array}$ & $2.8 \pm 0.4^{\mathrm{A}}$ & $2.5 \pm 0.3^{\mathrm{A}}$ & $6.0 \pm 1.4^{\mathrm{A}}$ \\
& & & \\
$200 \%-F e d$ & $3.7 \pm 0.6^{\mathrm{A}}$ & $3.4 \pm 0.8^{\mathrm{A}}$ & $7.8 \pm 1.2^{\mathrm{B}}$ \\
Day 2 & $5.4 \pm 1.6^{\mathrm{B}}$ & $4.9 \pm 0.8^{\mathrm{B}}$ & $15.3 \pm 1.7^{\mathrm{C}}$ \\
Day 7 & $4.2 \pm 0.9^{\mathrm{B}}$ & $5.3 \pm 0.9^{\mathrm{B}}$ & $20.3 \pm 3.4^{\mathrm{D}}$ \\
Day 14 & $10.5 \pm 2.0^{\mathrm{C}}$ & $12.6 \pm 2.3^{\mathrm{C}}$ & $30.0 \pm 2.0^{\mathrm{E}}$ \\
Day 21 & $13.5 \pm 2.1^{\mathrm{D}}$ & $13.4 \pm 2.8^{\mathrm{C}}$ & $33.9 \pm 4.0^{\mathrm{F}}$ \\
Day 32 & & & \\
One-way ANOVA & & & \\
F (df) P & $9.0(29), 0.0001$ & $9.3(29), 0.001$ & $20.4(28), 0.001$ \\
lsd $\mathrm{A}_{0.05}$ & 1.28 & 1.46 & 0.69 \\
\hline
\end{tabular}

Values are expressed as $10^{-6}$ cells per depot. Data are means \pm SEM for five rats per group and those within a column that do not share a common superscript are significantly different at $P<0.05$. Small samples of adipose tissue $(\sim 50 \mathrm{mg})$ were fixed in osmium tetroxide and cell number was determined by Coulter Counter.

\section{RETROPERITONEAL FAT}
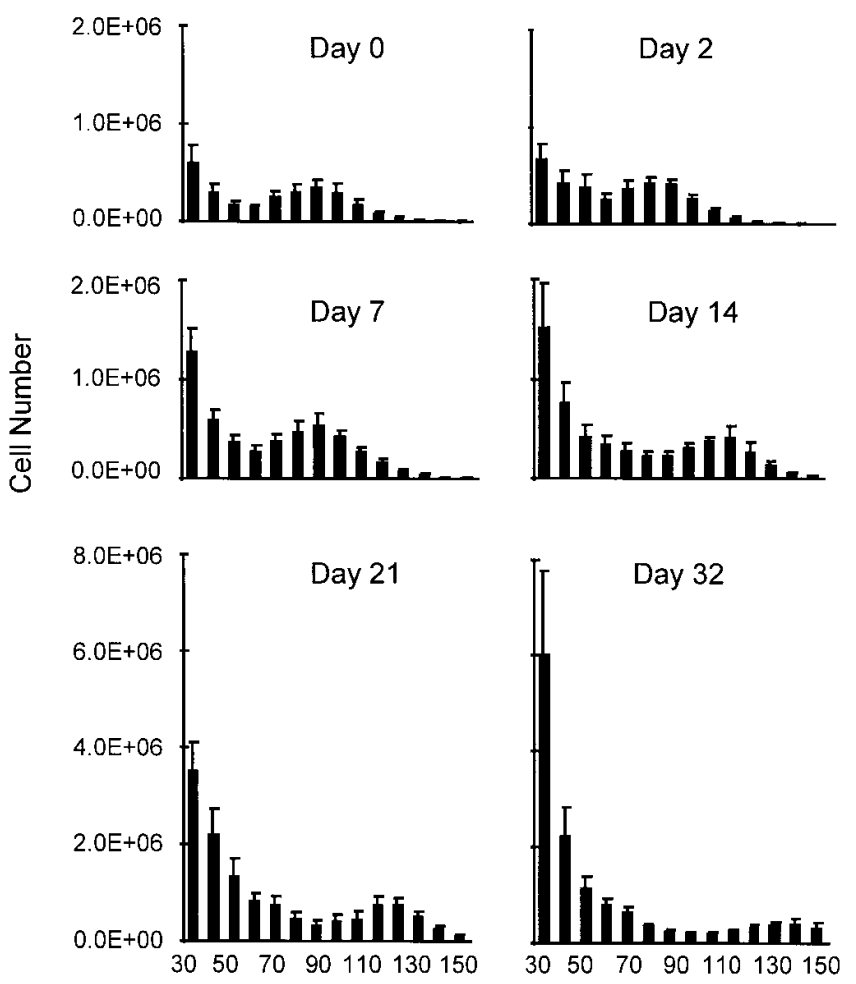

\section{Cell Diameter (um)}

Figure 1. Cell size distribution in retroperitoneal fat. Small samples of adipose tissue were fixed in osmium tetroxide and cell number and diameter were determined by Coulter Counter and Channelizer. The values are means \pm SEM for five rats per group. In the groups of $200 \%$-fed rats, which contained eight animals, the heaviest, lightest, and medium weight rats were excluded from cellularity measurements. The lower limit of the Channelizer prohibited measurement of cells with diameters $<30 \mu \mathrm{m}$.

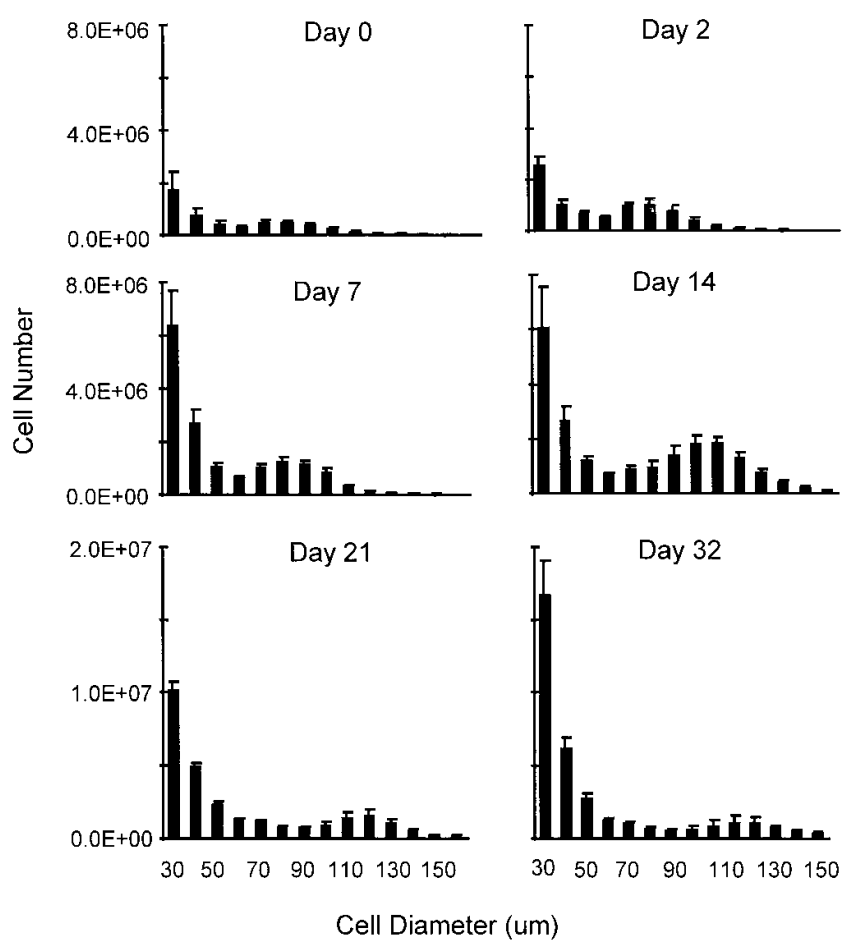

Figure 2. Cell size distribution in inguinal fat. Small samples of adipose tissue were fixed in osmium tetroxide and cell number and diameter were determined by Coulter Counter and Channelizer. The values are means \pm SEM for five rats per group.

with the rats killed on day 0 . The increase was attributable almost entirely to an increased population of small adipocytes without any substantial change in the number of larger adipocytes. However, as obesity developed the median size of the population of large cells increased from $90 \mu \mathrm{m}$ to $130-150 \mu \mathrm{m}$ in diameter, whereas the median size of the small cells did not increase as obesity progressed. These data support the hypothesis that small and large adipocytes are two independent cell populations that may have different metabolic and regulatory characteristics (14).

Retroperitoneal ob mRNA expression showed a two-phase response to tube-feeding, as shown in Fig. 4. A representative example of a Northern blot from this experiment is shown in Fig. 5. There was a significant, threefold increase in expression by day 2 in both $100 \%$-fed and $200 \%$-fed rats. At this time point the animals had received a total of six tube-fed meals and the degree of overfeeding in $200 \%$-fed rats was minimal. Food intake during the $48 \mathrm{~h}$ before time of killing was 35.8 grams in $100 \%$-fed rats, 38.0 grams in $200 \%$-fed rats, and $33.0 \pm 1.7$ grams in day 0 ad libitum animals. ob mRNA expression remained significantly higher in $100 \%$-fed than ad libitum rats throughout the experiment, indicating that a secondary, nonadapting aspect of meal-feeding stimulated ob expression either directly or indirectly. Regression analysis of data collected on days 0,2 , and 7 between ob expression and adipose and serum hormones (see Table $\mathrm{V}$ ) indicated significant correlations with fat pad weight and cell number. Therefore, it is possible that the early stimulation of ob expression occurred in response to the filling of small adipocytes. This would be consis- 
PERIRENAL FAT
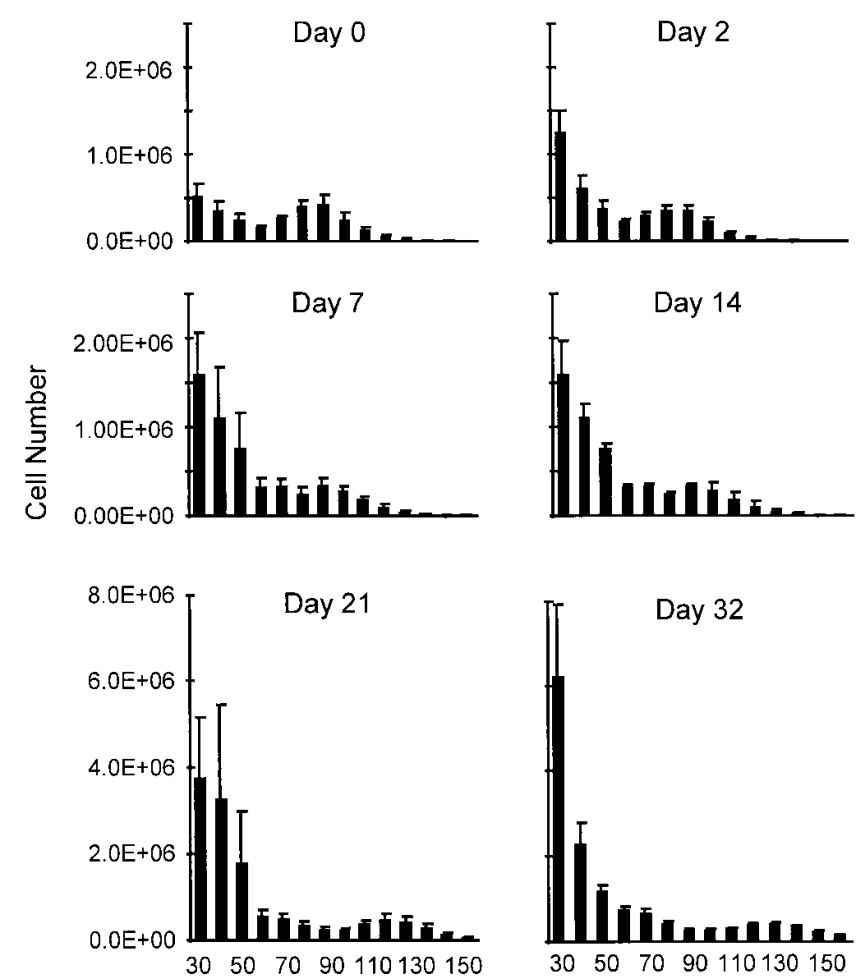

Cell Diameter (um)

Figure 3. Cell size distribution in perirenal fat. Small samples of adipose tissue were fixed in osmium tetroxide and cell number and diameter were determined by Coulter Counter and Channelizer. The values are means \pm SEM for five rats per group.

tent with results reported by Hamilton et al. (7) who demonstrated an increase in ob mRNA with lipid filling of human adipocytes.

The early increase in ob mRNA expression that was observed in all tube-fed rats after only $2 \mathrm{~d}$ of meal-feeding is diffi-

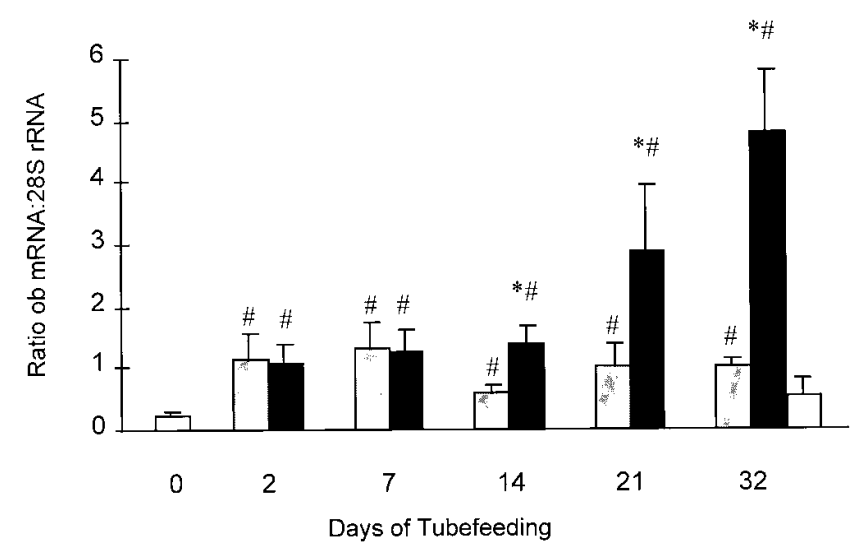

Figure 4. ob mRNA expression in retroperitoneal fat from rats killed after different periods of tube-feeding: white bars, ad libitum; shaded bars, $100 \%$-fed; and black bars, $200 \%$-fed. Values are means \pm SEM for five rats per group and are standardized to $28 \mathrm{~S}$ rRNA. *Significant difference between $200 \%$-fed and $100 \%$-fed animals, determined by $t$ test. "Significant difference from the value measured for day 0 ad libitum animals, determined by one-way ANOVA.

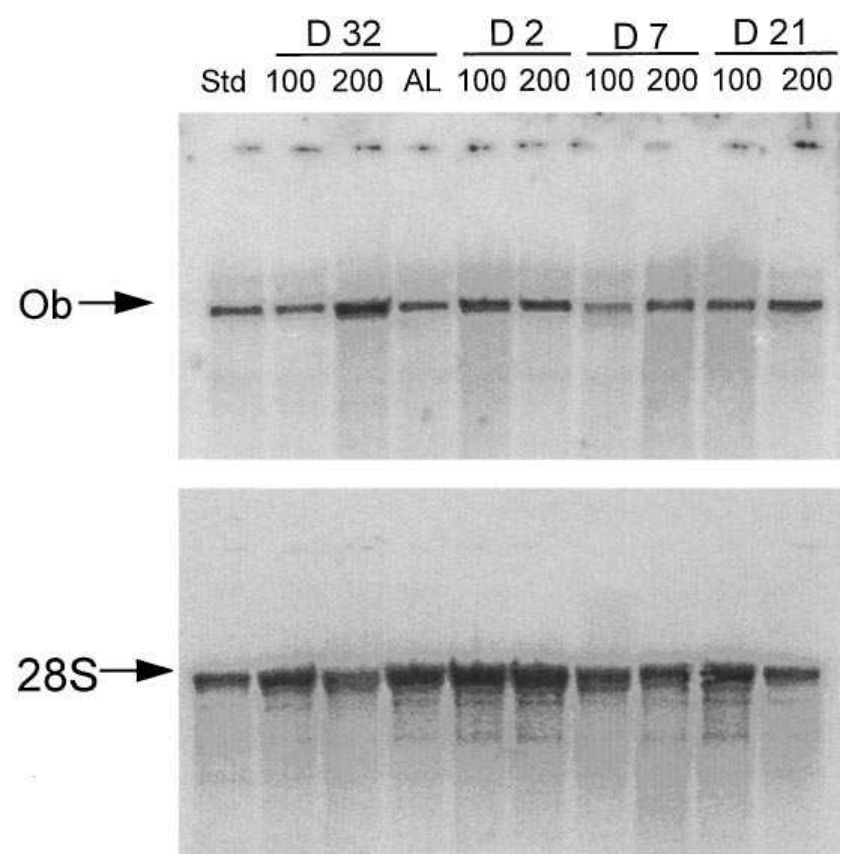

Figure 5. Northern blot analysis of ob mRNA and 28S rRNA in samples of retroperitoneal fat. Rats were tube-fed either their normal food intake (100) or twice normal intake (200) for different periods of time, or had eaten ad libitum $(A L)$ for $32 \mathrm{~d}$. ob mRNA was detected with a 320 -base cDNA probe and $28 \mathrm{~S}$ was detected on the same membranes with an oligonucleotide probe as described in Methods.

cult to explain in the context of ob protein functioning as a lipostatic feedback signal. Saladin et al. (15) reported that feeding rats that had been fasted overnight returned depressed levels of ob mRNA to control levels, requiring a twofold increase in expression. In this experiment the levels of ob mRNA in the tube-fed animals were threefold higher than control levels in ad libitum fed animals, therefore, the change in ob mRNA expression represented stimulation compared with the restoration in refed starved rats. On day 2 there were no significant changes in body fat content of meal-fed rats, however, it is possible that the early increase in ob mRNA expression was secondary to an increase in sympathetic tone. Peripheral sympathetic tone is depressed in several of the models of obesity (16) in which increased levels of ob mRNA have been reported, including ventromedial hypothalamus-lesioned rats (6), Osbourne Mendel rats (17), and adrenally intact Zucker rats (18). In these animals the feedback stimulation of sympathetic activity by positive energy balance also appears to be disrupted (16). Feeding rats a meal (19) or a high fat diet (20) stimulates both the sympathetic nervous system and ob mRNA expression (17). In contrast, starvation suppresses the sympathetic activity (21) and expression of ob mRNA is downregulated (15). These observations suggest a relationship between basal sympathetic tone and ob mRNA expression. Either the protein could activate mechanisms that increase energy expenditure when energy intake exceeds energy requirements, or, conditions that activate the sympathetic nervous system also promote release of ob protein. In this experiment rats were fed meals containing large amounts of simple carbohydrate which would be expected to stimulate sympathetic activity $(19,22)$. However, as there were no statistically significant differences in serum corticosterone in this experi- 
Table V. Regression Analysis for ob $m R N A$ Expression in Retroperitoneal Fat

\begin{tabular}{lcccc}
\hline & $R$ & $R^{2}$ & F ratio $(n)$ & Significance \\
\hline Days 0-7 & & & & \\
$\quad$ Pad weight & 0.48 & 0.23 & $6.4(22)$ & 0.02 \\
Cell number & 0.76 & 0.58 & $13.7(11)$ & 0.004 \\
Median cell size & 0.28 & 0.08 & $0.9(11)$ & 0.4 \\
Insulin & 0.39 & 0.15 & $3.7(22)$ & 0.07 \\
Corticosterone & 0.28 & 0.08 & $1.8(22)$ & 0.2 \\
Days 0-32 & & & & \\
Pad weight & 0.79 & 0.62 & $88.1(54)$ & 0.001 \\
Cell number & 0.56 & 0.31 & $9.16(21)$ & 0.007 \\
Median cell size & 0.72 & 0.52 & $21.9(21)$ & 0.0001 \\
Insulin & 0.47 & 0.22 & $14.9(53)$ & 0.0003 \\
Corticosterone & 0.21 & 0.05 & $1.5(31)$ & 0.2 \\
& & & & \\
\hline
\end{tabular}

Regression analyses were performed using Microsoft Excel 5.0 (Microsoft Corp.) assuming a linear relationship.

ment, further experiments are required to determine whether there is any direct relationship between sympathetic activity and the rapid increase in ob mRNA expression observed in tube-fed animals.

On day 14 there was a significant difference between $100 \%$-fed and $200 \%$-fed rats but this was due to a reduction in ob mRNA expression in $100 \%$-fed rats rather than an increase in $200 \%$-fed animals. By day 21 ob mRNA in overfed rats was significantly increased compared with $100 \%$-fed animals and on day 32 ob mRNA expression was 5-fold higher in $200 \%$ fed than $100 \%$-fed animals and 10 -fold higher than in ad libitum animals killed at the same time. Regression analysis of ob mRNA level against various other parameters measured in the rats between days 0 and 32 showed significant correlations with pad weight, cell number, median cell diameter of the larger cell population, and serum insulin concentration (see Table V). For the purposes of this experiment the large cell population was defined as cells with a diameter greater than the nadir of the distribution in the range of 50-100 $\mu \mathrm{m}$. For example, in retroperitoneal fat on day 0 , cells $>60 \mu \mathrm{m}$ were considered to represent the large cell population. On day 21, cells $>90 \mu \mathrm{m}$ were taken to be the large cell population. Further experiments are needed to elucidate whether ob mRNA expression is stimulated by hyperplasia, hypertrophy, or both, in adipose tissue. However, the hypothesis that ob mRNA expression is stimulated in response to hypertrophy rather than hyperplasia is supported by the development of a correlation with median cell diameter of larger cells as the rats became obese. In addition, the correlation between ob RNA and cell number was weaker when considered over days 0-32 than over days $0-7$, suggesting that hyperplasia may be less important than early filling of small cells. Again this would be consistent with the results of Hamilton et al. (7) who showed that ob mRNA expression increased with cell size in human adipose tissue. Further experiments are needed to determine whether filling of small adipocytes has a greater effect than filling of large adipocytes on ob mRNA expression.

The correlation with serum insulin concentration indicates that ob expression increases as the rats become insulin insensitive. There is insufficient data in this experiment to determine whether the correlation with insulin in overfed rats is due to a direct interaction between ob protein and insulin, or whether it can be explained by the simultaneous development of insulin insensitivity with the progression of obesity. However, observations from other experiments suggest an interaction between insulin status and ob mRNA level. ob mRNA expression is suppressed in rats made diabetic by streptozotocin injection and returned to normal when the diabetic rats are treated with insulin (23). Cusin et al. (24) and Saladin et al. (15) have demonstrated that acute or chronic insulin infusion causes a twofold increase in ob mRNA expression in rats. Pelleymounter et al. (8) demonstrated that low doses of ob protein corrected serum insulin and glucose concentrations in $o b /$ $o b$ mice in the absence of significant changes in food intake or body composition. In addition, the parabiosis experiment that provided the original evidence for ob protein as a feedback signal demonstrates a strong effect of ob protein on circulating insulin concentration (2). When genetically obese $o b / o b$ mice were parabiosed to lean littermates their serum insulin concentrations fell to one-tenth the level found in single $o b / o b$ mice. This change in insulin status was much greater than the changes in body weight or food intake that are considered to be evidence for mutation of a feedback satiety signal in $o b / o b$ mice (2). Taken together these observations suggest that ob protein secretion and insulin status of an animal are interdependent.

The relative levels of ob mRNA in different fat pads on days $0,2,14$, and 32 are shown in Fig. 6 . There were large differences in the level of ob mRNA in different fat pads, as reported previously by Ogawa et al. (25). The level of expression and pattern of change with time were similar in gonadal fat to those in retroperitoneal fat. ob mRNA expression was substantially lower in inguinal and perirenal fat. In inguinal fat there was no significant increase in ob expression on day 2 when the number of measurable cells in the depot had increased significantly (see Table III). In perirenal fat ob mRNA

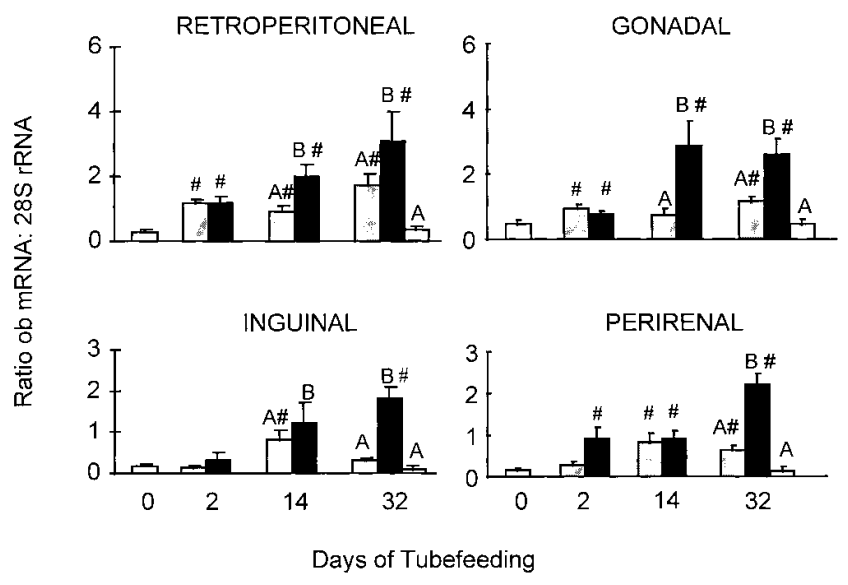

Figure 6. ob mRNA expression in four fat depots. Samples were obtained from rats that had been tube-fed either their normal food intake (shaded bars) or twice this amount (black bars) for 0,2,14, or $32 \mathrm{~d}$. Samples were also obtained from ad libitum fed animals (white bars) on days 0 and 32 . Values are means \pm SEM for five rats per group and are standardized to $28 \mathrm{~S}$ rRNA. ${ }^{\mathrm{AB}}$ Significant difference between $200 \%$-fed and $100 \%$-fed animals, determined by $t$ test. "Significant difference from the value measured for day 0 ad libitum animals, determined by one-way ANOVA. 
Table VI. Regression Analysis of ob mRNA Expression in Four Fat Depots

\begin{tabular}{lcccl}
\hline & $R$ & $R^{2}$ & F ratio $(n)$ & Significance \\
\hline Inguinal fat & & & & \\
$\quad$ Pad weight & 0.74 & 0.56 & $45.7(37)$ & 0.001 \\
Cell number & 0.70 & 0.49 & $11.7(13)$ & 0.005 \\
$\quad$ Median cell size & 0.83 & 0.70 & $28.6(13)$ & 0.001 \\
Insulin & 0.28 & 0.08 & $3.1(35)$ & 0.09 \\
Corticosterone & 0.16 & 0.02 & $0.9(36)$ & 0.4 \\
Ovarian fat & & & & \\
Pad weight & 0.56 & 0.32 & $16.8(37)$ & 0.0002 \\
Insulin & 0.34 & 0.11 & $4.37(35)$ & 0.04 \\
Corticosterone & 0.25 & 0.06 & $2.35(36)$ & 0.13 \\
Retroperitoneal fat & & & & \\
$\quad$ Pad weight & 0.69 & 0.47 & $32.3(37)$ & 0.0001 \\
Cell number & 0.60 & 0.36 & $8.0(15)$ & 0.01 \\
Median cell size & 0.33 & 0.11 & $1.7(15)$ & 0.2 \\
Insulin & 0.44 & 0.20 & $8.28(35)$ & 0.006 \\
Corticosterone & 0.51 & 0.27 & $12.77(36)$ & 0.001 \\
Perirenal fat & & & & \\
$\quad$ Pad weight & 0.74 & 0.54 & $41.47(36)$ & 0.0001 \\
Cell number & 0.73 & 0.53 & $15.98(15)$ & 0.001 \\
Median cell size & 0.79 & 0.62 & $23.2(15)$ & 0.0003 \\
Insulin & 0.36 & 0.13 & $4.76(34)$ & 0.04 \\
Corticosterone & 0.34 & 0.12 & $4.4(35)$ & 0.04 \\
& & & & \\
\hline
\end{tabular}

Regression analyses were performed using Microsoft Excel 50 (Microsoft Corp.) assuming a linear relationship.

expression was significantly increased in $200 \%$-fed but not $100 \%$-fed rats by day 2 . As described previously the differences in food intake by this time were negligible but perirenal fat pad weight was close to being significantly different $(P<$ $0.06)$ between the two groups. Unlike the three other fat pads measured there was no difference in perirenal ob mRNA expression between $100 \%$-fed and $200 \%$-fed rats until day 32 .

The results of regression analyses between ob mRNA level in different fat pads and their respective pad weights, cell number, and cell size are shown in Table VI. The level of ob expression correlated with fat pad weight for all four fat depots. In those pads in which cell number and size had been determined, ob expression showed a high correlation with cell number and with median size of large cells in inguinal and perirenal fat. Ovarian, perirenal, and retroperitoneal ob mRNA correlated with serum insulin concentration. Retroperitoneal and perirenal ob mRNA correlated with corticosterone, suggesting a difference in depot sensitivity to hormone regulation of ob mRNA expression.

The results from this experiment demonstrate that obesity is not required to stimulate ob mRNA expression. Meal-feeding caused a rapid threefold increase in expression in the absence of a significant increase in either food intake or fat pad weight. A second increase in expression occurred when overfed rats were $\sim 130 \%$ of control weight and fat pads had more than doubled in size. Further studies are required to confirm that ob expression is stimulated by filling of both small and large adipocytes. Further investigation will elucidate the relationship between insulin status of an animal and ob protein secretion.

\section{References}

1. Coleman, D.L., and K.P. Hummel. 1969. Effects of parabiosis of normal with genetically diabetic mice. Am. J. Physiol. 217:1298-1304.

2. Coleman, D.L. 1973. Effects of parabiosis with diabetes and normal mice. Diabetologia. 9:294-298.

3. Parameswaran, S.V., A.B. Steffens, G.R. Hervey, and L. de Ruiter. 1977. Involvement of a humoral factor in regulation of body weight in parabiotic rats. Am. J. Physiol. 232:R150-R157.

4. Harris, R.B.S., and R.J. Martin. 1984. Specific depletion of body fat in parabiotic partners of tube-fed obese rats. Am. J. Physiol. 247:R380-R386.

5. Zhang, Y., R. Proenca, M. Maffel, M. Barone, L. Leopold, and J.M. Friedman. 1994. Positional cloning of the mouse obese gene and its human homologue. Nature (Lond.). 372:425-432.

6. Funahashi, T., I. Shimomura, H. Hiraoka, T. Arai, M. Takahashi, T. Nakamura, S. Nozaki, S. Yamashita, K. Takemura, K. Tokunaga, and Y. Matsuzawa. 1995. Enhanced expression of rat obese (ob) gene in adipose tissues of ventromedial hypothalamus (VMH)-lesioned rats. Biochem. Biophys. Res. Commun. 211:469-475.

7. Hamilton, B.S., D. Paglia, A.Y.M. Kwan, and M. Deitel. 1995. Increased obese mRNA expression in omental fat cells from massively obese humans. $\mathrm{Na}$ ture Medicine. 1:953-955.

8. Pelleymounter, M.A., M.J. Cullen, B. Baker, R. Hecht, D. Winters, T. Boone, and F. Collins. 1995. Effects of the obese gene product on body weight regulation in ob/ob mice. Science (Wash. DC). 269:540-543.

9. Campfield, L.A., F.J. Smith, Y. Guisez, R. Devos, and P. Burn. 1995. Recombinant mouse OB protein: evidence for peripheral signal linking adiposity and central neural networks. Science (Wash. DC). 269:546-549.

10. Halaas, J.L., K.S. Gajiwala, M. Maffei, S.L. Cohen, B.T. Chait, D. Rabinowitz, R.L. Lallone, S.K. Burley, and J.M. Friedman. 1995. Weight-reducing effects of the plasma protein encoded by the obese gene. Science (Wash. DC). 269:543-546.

11. Harris, R.B.S., and R.J. Martin. 1989. Changes in lipogenesis and lipolysis associated with recovery from reversible obesity in mature female rats. Proc. Soc. Exp. Biol. Med. 191:82-89.

12. Harris, R.B.S., and R.J. Martin. 1986. Metabolic response to a specific lipid-depleting factor in parabiotic rats. Am. J. Physiol. 250:R276-R286.

13. Bjorntorp, P., M. Karlsson, and P. Pettersson. 1982. Expansion of adipose tissue storage capacity at different ages in rats. Metab. Clin. Exp. 31:366373 .

14. Francendese, A., and F.D. DeMartinis. 1985. Very small fat cells. II. Initial observations on basal and hormone-stimulated metabolism. J. Lipid Res. 26:149-157.

15. Saladin, R., P. De Vos, M. Guerre-Millo, A. Leturque, J. Girard, B. Staels, and J. Auwerx. 1995. Transient increase in obese gene expression after food intake or insulin administration. Nature (Lond.). 377:527-529.

16. Bray, G.A. 1991. Obesity, a disorder of nutrient partitioning: the MONA LISA hypothesis. J. Nutr. 121:1146-1162.

17. Lin, X., D.A. York, R.B.S. Harris, and R.C. Bruch. 1995. The effect of high-fat diets on expression of Ob mRNA in a model of diet induced obesity. Obesity Res. 3(Suppl. 3):389s.

18. Lin, X., D.A. York, R.B.S. Harris, G.A. Bray, and R.C. Bruch. 1995. The effect of adrenalectomy and glucocorticoid replacement on Ob mRNA levels in adipose tissue of obese Zucker ( $f a / f a$ ) rats. Obesity Res. 3(Suppl. 3):339s.

19. Lupien, J.R., Z. Glick, M. Saito, and G.A. Bray. 1985. Guanosine diphosphate binding to brown adipose tissue is increased after a single meal. Am. J. Physiol. 249:R694-R698.

20. Schwartz, J.H., J.B. Young, and L. Landsberg. 1983. Effect of dietary fat on sympathetic nervous system activity in the rat. J. Clin. Invest. 72:361-370.

21. Young, J.B., and L. Landsberg. 1977. Suppression of sympathetic nervous system during fasting. Science (Wash. DC). 196:1473-1475.

22. Young, J.B., and L. Landsberg. 1977. Stimulation of the sympathetic nervous system during sucrose feeding. Nature (Lond.). 269:615-617.

23. MacDougald, O.A., C.-S. Hwang, H. Fan, and M.D. Lane. 1995. Regulated expression of the obese gene product (leptin) in white adipose tissue and 3T3-L1 adipocytes. Proc. Natl. Acad. Sci. USA. 92:9034-9037.

24. Cusin, I., A. Sainsbury, P. Doyle, F. Rohner-Jeanrenaud, and B. Jeanrenaud. 1995. The ob gene and insulin. A relationship leading to clues to the understanding of obesity. Diabetes. 44:1467-1470.

25. Ogawa, Y., H. Masuzaki, N. Isse, T. Okazaki, K. Mori, M. Shigemoto, N. Satoh, N. Tamura, K. Hosoda, Y. Yoshimasa, et al. 1995. Molecular cloning of rat obese cDNA and augmented gene expression in genetically obese Zucker fatty $(\mathrm{fa} / \mathrm{fa})$ rats. J. Clin. Invest. 96:1647-1652. 